\title{
Hikmah and Narratives of Change: How Different Temporalities Shape the Present and the Future in Post-Tsunami Aceh
}

\author{
Annemarie Samuels
}

Why in Aceh? God has not yet given [the tsunami] to other people, He gave [it] to Aceh first, right? Perhaps it is also a test. Now people live according to Shari'a rules again, perhaps it was a test. A warning, so that the Acehnese will become better people in the future.

PAK JAMALUDDIN, owner of a coffeehouse, December 2007

The tsunami that struck Aceh on 26 December 2004 left a trail of death and destruction. ${ }^{1}$ It also brought about social changes and hopes for better futures. The post-tsunami years in Banda Aceh were full of different ideas about improvement, as many people felt that the tsunami had created opportunities for building a better society. The two major normative frameworks for improvement, which I call 'improvement narratives,' were that of moral and religious 'improvement' on the one hand and socio-economic 'development' on the other. ${ }^{2}$ In this chapter, I will show that aspirations for and expectations of these

1 The fieldwork on which this chapter is based was made possible by the generous financial support of Leiden University, the Catharine van Tussenbroek Fonds, the Leiden University Fund, and the Aceh Research Training Institute (ARTI). I am very grateful to Patricia Spyer for her inspiring comments on earlier drafts of this chapter. I thank Michael Feener and David Kloos, who have read several versions of this chapter and provided me with most valuable suggestions for improvement. Finally, I wish to thank all the participants of the Leiden workshop for their thoughtful comments and the stimulating discussions.

2 In this chapter, I use the concept of 'improvement narratives' to refer to these two specific normative frameworks for change. I use the concept of 'imaginaries' to discuss ideas about the future more broadly. Finally, the concept of 'discourse' will be reserved for all other publicly articulated ideas about society. 
kinds of improvement were closely intertwined in people's everyday lives in the years after the tsunami.

These improvement narratives were shaped by different concepts of time: whereas the narrative on moral improvement builds on an apocalyptic concept of time in which the expectation of the future end of the world influences present actions, the narrative on socio-economic development builds on a temporality of never-ending growth. However, although based on different concepts of time, through both narratives the tsunami came to figure as a starting point, or even an opportunity, for change. These improvement narratives emerged within contexts of rapidly changing institutions and the promotion of state discourses on development and on the strengthening of Islamic law (Feener 2013; Phelps et al. 2011). In this chapter, I will focus on the improvement narratives of ordinary Muslims in Banda Aceh, showing how they were informed, but never completely determined by state discourses, while simultaneously building on different temporalities and aspirations for the future. I argue that the tsunami heightened the importance of certain temporal relations, connecting the past, present, near and distant futures in new ways that both made a sense of the 'end of days' imminent, and opened up new possibilities for 'improvements' of various kinds in the near future.

To understand the improvement narratives of Islam and socio-economic development in contemporary Aceh, it is crucial to explore the diverse ways in which people there have come to understand and explain the tsunami. Many people in Banda Aceh discuss the past experiences of the disaster in relation to the future-oriented imaginaries of both actual and aspirational social and personal change. Among these future imaginaries, the two improvement narratives discussed in this chapter stand out, because of their importance to both public debates and personal ways of understanding the disaster. These improvement narratives were fundamentally influenced by different conceptions of time, two of which will be discussed in detail in this chapter.

The first is what might be considered an 'Islamic' conception of time. Although space doesn't allow me to engage with the encompassing topic of time and Islam comprehensively here, in light of the discussions in this chapter it is important to briefly discuss the centrality of the notions of fate, eternity and the Day of Judgment in Islamic conceptions of time. Gerhard Böwering has shown how the Qur'an breaks with pre-Islamic notions of time as it puts destiny into the hands of God. This means that God determines everything that happens, including the beginnings and ends of the lives of individuals (Böwering 1997, 57). Early Muslim philosophers and theologians developed Greek ideas on atomism to show that God created the world anew in every moment within 
eternity (op. cit. 59). Most important, perhaps, in the context of this chapter are the notions of the Day of Covenant (the moment of creation) and the Day of Judgment (when the world will end and individuals will be judged), which are both "anchored in eternity" (op. cit. 6o). In Aceh, this conception of time in which the world has a beginning and an end, informed the idea that the tsunami signalled that the end of the world was approaching. Interpreted as a God-given warning, test, or punishment, many Muslims explained the tsunami as a sign that they should improve their religiosity in the present to ensure a better position in the afterlife. ${ }^{3}$

A second influential conception of time is a linear and progressive one. It is this idea of time that underlies the improvement narrative of socio-economic development, which promises never-ending progress. In Indonesia, this view of development has been promoted by the state since the colonial period (Li 1999, 2007). It became the state philosophy during the New Order, and gained new momentum in Aceh after the tsunami (see Feener 2013). However, for many people in Aceh, progress is not just a linear temporal process, but also a return to a mythic past of a glorious, prosperous and cosmopolitan Aceh. Arguably, this nostalgic notion of the return to a glorious past as a way of progress toward the future might be considered a third conception of time influencing the two above-mentioned improvement narratives. Importantly, these different conceptions of time as well as the different improvement narratives do not only coexist, but are also entangled in everyday life and in the explanations for the occurrence of the tsunami. References to the different improvement narratives are selectively deployed by people in Aceh in relation to shifting contexts (for example in discussions on morality and society and in discussions on the economy or foreign relations).

In this chapter, I will suggest that the way in which, after the tsunami, people used the Islamic concept of hikmah (divine wisdom) signals the intersection of the two improvement narratives. By pointing out that hikmah could be seen in the tsunami's intended effects on both morality and socio-economic development, the post-tsunami use of the concept of hikmah exemplifies the long-term connections between religious ideals and modern ideologies of development (Feener 2013).

My focus on future imaginaries contributes to a growing body of literature on Islam and everyday life in Aceh (Birchok 2013; Ihsan 2010; Kloos this volume,

3 Below, I will discuss some of the most common Islamic explanations for the tsunami. For detailed accounts of the repertoire of (religious) tsunami explanations, see Feener (2013), Feener and Daly (Forthcoming), Idria (2010), and Wieringa (2011). 
2013; Samuels 2012; Smith 2012). It is through this particular focus that I aim to emphasize how ideas about time and improvement not only developed in a specific historical context and gained momentum in the post-tsunami and post-conflict period, but also how, as temporal narratives making sense of the disaster, they became an important part of the remaking of the everyday after the tsunami.

This chapter results from my research project on the remaking of everyday life in post-tsunami Banda Aceh. For this project, I conducted ethnographic fieldwork in and around Banda Aceh for more than twelve months in total. ${ }^{4}$ During this time, I lived with two host families in tsunami affected neighbourhoods, one near Banda Aceh's city centre and the other seven kilometres outside the municipal boundaries in the district of Aceh Besar. I conducted indepth interviews and participant observation in the places where I lived, as well as in several other locations, including Banda Aceh's city centre, a severely affected fishermen's neighbourhood, and a relocation site 15 kilometres out of town. In the process of these interviews, I talked with men and women of different ages, class backgrounds and ethnicities. By focusing on their stories I aim to contribute to the understanding of the role of religion in post-disaster societies, thereby exploring the influences and limits of the state. After a brief introduction on the concepts of time and improvement, I will discuss Islamic tsunami explanations, the Islamic notion of hikmah that brings together different narratives of improvement, and the role of the developmental discourse in the post-tsunami society.

\section{Time and Improvement}

The tsunami brought to prominence two different conceptions of time, which are both intimately related to narratives of improvement. The first is a religious temporality, through which the tsunami was explained as making people aware of the imminent end of the world. The second is a developmental temporality, through which the tsunami was seen as providing an opportunity to embark upon a linear process of progress. In this section I will elaborate on the relation between these temporalities and post-tsunami narratives of improvement.

4 I conducted fieldwork for this project in Banda Aceh from October 2007 to March 2008, from February to August 2009, in May/June 2010 and in January 2012. 
Most people in Aceh give religiously informed explanations for the tsuna$\mathrm{mi}$-including those along the lines mentioned by PakJamaluddin, in the epigraph that opened this chapter. ${ }^{5}$ In this repertoire of explanations (which will be discussed in detail below), the tsunami is not only seen as a divine intervention, but also as an opportunity for Muslims to become more pious and for the society as a whole to improve morally. The need to become more pious is strongly anchored in the future end of the world. The way in which the future end inspires present actions is what Frank Kermode (1967) has called 'the sense of an ending.' In this religious temporality, there is a beginning and an end. People now are 'in the middest' but the end will certainly come and the living can still change their fate. This 'sense of an ending' bestows meaning on the present in relation to the expected future and influences present behaviour (Kermode 1967, 17; see also Spyer 2000). As Spyer $(2000,177)$ argues, "[i]n this way, social action becomes charged with a meaning and efficacy that ultimately derives from its relation to this end."

Interestingly, this 'messianic time' of the end is more about an understanding of the present than about the future. As Giorgio Agamben, drawing on the work of Walter Benjamin, has pointed out, messianic time is not about waiting for the Messiah to come, but about the potentialities of the present, for "the sole possibility to truly grasp the present is to conceive of it as the end." (Leland de la Durantaye 2009, 376, quoted from Agamben 2001). These reflections on the importance of the present in relation to the end of the world in a religious conception of time are not unrelated to Böwering's discussion of the Islamic philosophy of time-in which God creates the world anew in each moment and in which the Day of Judgment will be the end of the world anchored in eternity (Böwering 1997). It is this religious conception of time (akin to what Benjamin called "messianic time") that was strengthened by the tsunami.

Yet it is important to note that the appeals of the distant future of the 'end' and the afterlife, as well as the call for near future reform in this world, are not new to Aceh. James Siegel has analysed the focus on paradise and the afterlife in his discussion of the Hikayat Prang Sabi ('Story of the Holy War'), the popular epic narrating the war against the Dutch (Siegel 1979) and the change toward a focus on this-worldly Islamic reform from the 1930s onwards (Siegel 2000 [1969]). ${ }^{6}$ Like the war against the Dutch (which started in 1873), the tsunami

5 All the personal names that I use in this paper to refer to my interlocutors in Aceh are pseudonyms.

6 According to Siegel's account, the appeal of worldly Islamic reform movements was highly gendered. It was the men who superseded village level social structures to connect to the 
foregrounded the idea of the end of the world and therefore instilled the need for religious improvement with a particular sense of urgency. ${ }^{7}$

Becoming more pious, however, is not the only form of moral improvement that people in Aceh are concerned with. As anthropologists of Islam have recently argued, in everyday life different "moral registers" coexist or sometimes painfully contradict each other (Schielke 2009a; see also Kloos this volume; Marsden 2005, 2009; Schielke 2009b; Soares 2006), for example when Islamic ideals of chastity are confronted with expectations of romantic love, or when aspirations of consumption and well-being are confronted with religious disregard for attachment to worldly possessions (Schielke 2009b). "Morality in this sense," Schielke argues, "is not only unsystematic and ambiguous, it is also accompanied by declaredly amoral aims and strategies that people deem necessary to fill the 'emptiness' of the everyday and to reach material wellbeing" (2009a, s31). Others have analysed this ambiguity in the context of islam mondain, emphasizing that religious values and ethical working on the self do not exclude worldly aspirations (Otayek and Soares 2007; Soares and Osella 2009, S11-S12. For discussions on this topic in the Southeast Asian context, see Fealy and White 2008; Njoto-Feillard 2012; Rudnyckyj 2010).

Although these different kinds of aspirations are not necessarily without tensions, in this chapter I emphasize how they coexist in Aceh's post-tsunami everyday. ${ }^{8}$ The moral and religious improvement deemed necessary in light of the coming end of the world by no means excluded people's aspirations

rope of God.' Siapno (2002) shows that, at least during her research in the 1990s, this was not the case (anymore). Many of the ideas about the tsunami and the future described in this chapter were voiced by men as well as women. My point is not to downplay gender differences in imaginings of the future, but to underscore that women as well as men create and recreate these broadly shared ideas about improvement and temporality.

7 As Edwin Wieringa has shown, the Acehnese war literature warns that sinfulness is causing disaster (in this case the Aceh war) and that the Acehnese can only reach paradise by committing to their faith through fighting the Holy War against the Dutch (Wieringa 1998; see also Feener 2013). Interestingly, the Hikayat Prang Sabi became popular again in the context of another recent moment of significant social transformation in Aceh, namely the 1999 peaceful social movement that demanded a referendum about Acehnese independence from Indonesia (Kloos forthcoming).

8 In public debate, different moral registers indeed may stand in a hierarchical relation. As Schielke (2009a, s32) remarks about Egypt: "While values can be debated, declaring them religious often ends the debate. All other moral registers have either to accept or ignore the supremacy of religion, but they cannot openly contest it." However, in everyday life, people draw on different moral registers without reflecting on them all, or by painfully admitting that they cannot live up to the standards of perfect piety (Schielke 2009a; 2009b). 
and expectations of more 'worldly' future improvement. People in Aceh frequently voiced aspirations for, especially, improvement of personal and collective material well-being and improvement of Aceh's international position, its place-in-the-world (Ferguson 2006). Different from the religious 'sense of an ending,' these aspirations echo the development discourse that builds on a temporality of linear and never-ending progress; a process in which the tsunami formed a new and dramatic intervention.

After the tsunami, many people expressed their hopes for improvement of the educational system and for more economic investments that would lead to more jobs and prosperity. They hoped that the international attention for Aceh, which came about because of the tsunami, would secure lasting international recognition, attract tourists and economic investment, and increase the possibilities for studying abroad and traveling for business. Young men and women in particular aspired for economic improvement that would enable them to pursue their studies, start businesses and enjoy a middle-class lifestyle that would include hanging out in Banda Aceh's new hip road side cafés or the relatively expensive Pizza Hut, using internet on a smart phone and driving a car or a brand new motorcycle. As much as these aspirations may be inspired by images of middle-class lifestyles circulating on television and in magazines, they were certainly also fuelled by the post-tsunami reconstruction industry that brought cafés, cars, and an air-conditioned shopping mall.

In this sense, the tsunami had the effect of increasing rather than diminishing the 'capacity to aspire' (Appadurai 2004), an increased sense that improvement toward the 'good life' was a real possibility. These aspirations, accompanied by expectations of modernity (Ferguson 1999), provide a strong and important imaginary of the future in post-tsunami Aceh. However, when 'modernity' does not come as expected, or not for all, the unfulfilled promise of money and status may cause great frustration and disappointment (Ferguson 1999; Schielke 2009b).

The appeal of the development discourse of improvement toward modernity was not only part of a long tradition of 'development' in Indonesia (Anderson 1983; Heryanto 1988; Li 1999), but also informed by many changes in posttsunami and post-conflict Aceh. The peace agreement, political change, the presence of hundreds of national and international NGOS and governmental agencies with huge budgets and ambitious 'improvement schemes' (Li 2007), as well as the opening up of the province for travel, contributed to the improvement momentum. Crucially, improvement-in the form of development—was promised by the national government and international organizations that frequently used the phrase 'building back better' as the slogan for the work of post-tsunami reconstruction in Aceh. 'Building back better' is an ongoing effort 
in the present without necessarily having a clear end point in the future and lacking a view of the past. Connected to the popular disaster reconstruction approach of 'linking relief reconstruction and development' (LRRD), ${ }^{9}$ through 'building back better,' governments and aid agencies aim to go beyond immediate disaster relief and physical reconstruction to generate social and economic changes (Feener 2013). ${ }^{10}$ In Aceh, 'building back better' did not just include socio-economic development. As Feener (2013) points out, the Indonesian government promoted discourses of both development and of religious reform in Aceh after the tsunami.

Importantly, different ideas about the future evolve in a field of differential power relations. The voices of religious leaders, the Indonesian government, international organizations and other powerful actors influence, but do not totally determine the everyday expectations and aspirations I analyse in this chapter. Rather, people position themselves in relation to different narratives and imaginaries in the context of their daily lives. 'The will to improve' (Li 2007) was indeed the major drive for change in post-tsunami Aceh. However, this will was not only formulated by experts in 'improvement schemes,' but also voiced and acted upon by Islamic leaders and many ordinary Acehnese in diverse ways. It is through this continuous process of positioning, adjustment and interaction that we can look beyond the state and its official discourse on Islam and development, to discern their limits in the lived experiences of individuals and local communities.

It should be emphasized here that the post-tsunami idea of development was not only grounded in a state-developmental discourse, but also in a historically grown sense of Acehnese identity. The interpretation of the Acehnese past is very important in contemporary Aceh (Feener 2011, 19). Present expectations of Acehnese modernity both inform, and are informed by, the imaginary of Aceh's glorious past; evoking a nostalgia for the Acehnese Golden Age in the

9 For an early overview of the LRRD approach, see Buchanan-Smith and Maxwell (1994). For a critical account of the influence of this approach in the post-disaster reconstruction process in Aceh, see Christoplos and Wu (2012).

10 Based on a comparative study of 'Building back better' practices in post-tsunami Aceh and Sri-Lanka, Kennedy et al. (2008) conclude that because of the multiple interpretations one could give to 'better,' the slogan should be changed to 'building back safer.' 'Safer,' according to Kennedy et. al., applies both to highly technical aspects of reconstruction (such as physical structures) and to less technical aspects such as education and disaster risk reduction. Arguably, however, it is exactly the broad scope and versatility of the concept 'better' that allows governments and aid agencies to see the disaster as an opportunity for societal change and thereby put it to political use. 
pervasive aspiration to 're-connect' to globalization (see Ferguson 1999, 2008). ${ }^{11}$ An Acehnese identity as opposed to an Indonesian identity emerged in the second half of the twentieth century (Aspinall 2009, 46-47). The idea of the past and future glorious nation of Aceh developed first in relation to modernity and colonialism and as a part of Indonesian 'roots' and only later as opposed to Indonesia (ibid.).

Today, an Acehnese identity strongly influences how people in Aceh talk about the future. People often discuss the future (development) of 'Aceh' as a nation. After the tsunami, many people had the feeling that suddenly it had become possible not only to be part of the Islamic umma and the globalized world, but also to be part of modernity as Acehnese. Through this idea of the development of Aceh, the state's development discourse gets a particular local meaning. Before exploring this development discourse and temporality further, I will first look into Islamic interpretations of the tsunami and their relation to the development of Acehnese discourses on the imperative of moral improvement.

\section{God's Will}

Many Acehnese Muslims considered the tsunami to be takdir; fate or destiny. This meant that for the people who lost their lives in the tsunami the predestined time of death (ajal) had already come, while for the survivors apparently it had not come yet (belum ajal). A related, frequently used expression was that the survivors had been given more time to live (masih dikasih umur). Thus, according to many of my interlocutors, both those who died and those who survived were confronted through the tsunami with their predetermined fate (takdir).

The idea of a predestined future that is known by God but not by humans has a prominent presence in everyday life in Aceh. Fate is called upon to explain bad things that happen (musibah, disasters) and good things that happen (rezeki, fortune), although both musibah and especially rezeki, which also has other, related, meanings, may also be the consequence of past actions. In everyday speech, both insya' Allah (God willing) and kalau umur panjang (if

11 The Acehnese "Golden Age" (Zaman Mas) refers to the late sixteenth to early seventeenth century, when the Aceh sultanate was at the height of its power, and Islamic law was — or so it is assumed - forcefully upheld. Edward Aspinall describes this as Aceh's "first great historical myth" that would be "a recurrent motif for later sultans, rebels, Islamic scholars, Indonesian nationalists, and secessionists alike.” (Aspinall, 2009, 22). 
[we] live long enough) are frequently used when people talk about things that may happen in the future, indicating that people can never be sure that God wants it to happen that way. In short, as the notion of fate is deeply embedded in everyday life in Aceh, it is not surprising that it became important in the context of explaining the tsunami as well. ${ }^{12}$ For some people, referring to takdir meant that they did not question the meaning of the tsunami any further, as further explanations of why God had sent the disaster were mere possibilities; no one would ever know for sure. However, this did not prevent a majority of the people I spoke with from raising one or more of these possible explanations and pointing at signs that provided extra 'proof' (bukti) that the tsunami had been God's will.

Such 'proof' included foretelling signs that, in retrospect, predicted the tsunami, such as the particular behaviour of relatives who would die in the tsunami, dreams and visions, and stories about divine revelations or foretelling feelings. For example, some people told me how a pre-tsunami dream had been a sign of what was about to happen. Such was the experience of Ibu Rina, a young mother, who had lost many family members in the tsunami. She lived in one of Banda Aceh's neighbourhoods that had been seriously damaged, but after the tsunami she had quickly renovated her damaged house, together with her husband. In front of the house, they had made a small store in which she sold credit for mobile phones and worked as a tailor. While sitting in her store and talking about her experience of the tsunami on an afternoon in early 2008 , she told me about the dream she had on the night before the disaster: ${ }^{13}$

In this dream my mother and my younger sister came to me. My sister said: "Sister, please forgive me." That was in my dream. "Why do you ask for forgiveness? What have you done wrong?" [I asked.] I felt that my mother

12 For the Acehnese I spoke with, the emphasis on fate did not mean that in case of a calamity one could just sit and wait for death to come. Rather, as many people said, one should work to take care of oneself and others (berusaha).

13 Siegel (2000, 326-329) mentions three categories of dreams in Aceh, of which only one, loempòe, is 'true': "It is true, however, because it contains a message. It is a sign of what will happen. Moreover, it is sent not by djinns but by God." (op. cit. 328). Grayman et al. (2009) also encounter this category of dreams and add that people rarely discuss these dreams. In his famous nineteenth century ethnography, Snouck Hurgronje already wrote about premonitions and dream interpretations (mostly of foretelling dreams) (Snouck Hurgronje 1894, 43-46). These dream interpretations are part of the long-established Malayo-Muslim genre of Ta'bir Mimpi (Snouck Hurgronje 1894, 45; see also Overbeck 1929). On the history of visionary dreams in Islam, see Green (2003). 
was there. And then my mother said: "Just forgive." Alright, I forgive. But the following morning the tsunami came. They disappeared.

Only after the tsunami, Rina realized that this dream had announced their parting. Other people told me how strange behaviour of their relatives had been a sign of their coming deaths or how in retrospect their relatives had sensed that they would die. One of the people who told me such a story was Pak Nazaruddin. Before the tsunami, he had been a businessman in Jakarta, where he lived with his wife and children. His parents, who both died in the tsunami, had lived in their village of origin, a fishermen's neighbourhood in Banda Aceh, where his father had been a local imam. Soon after the tsunami, Pak Nazaruddin moved back to Aceh permanently to start his own shop in his old neighbourhood. In one of our conversations in his shop, he told me how perhaps his father had sensed his own death: "One month before the tsunami he called me [in Jakarta]. He asked all of us to come home; as if he already knew he would die." Pak Nazaruddin explained how his family in Aceh started to send all kinds of special Acehnese food to Jakarta and went on to say: "So I called him; and he asked to take the children home to Aceh. He meant that I should take them home to Aceh because, how did he say it, he said: perhaps I will die and then I won't see them again."14

Perhaps the most visible sign that was often referred to as an indication that the tsunami was given by God, was the image of mosques still standing in a landscape in which everything had been washed away. For most Acehnese, the pictures of the lonely mosques show God's power: while destroying everything, He left the mosques standing. Apart from such lasting images, many circulating miracle stories were interpreted as symbolizing the religious meaning, or hikmah (divine wisdom), of the event. Some were very personal. A teenager I knew well related how he became stuck in a net of barbed wire deep down in the water. He prayed and prayed that if the time of his death had come (ajal), God would make death come quickly, but that if he still had time to live, the wire would come loose. Immediately after his prayer, he could free himself. Others told me how they felt that they were picked up by a snake under water and lifted up to the surface or how they had seen that a sudden ray of light lifted people to the top of a mosque. Other stories tell of holy places that were spared by the water or how people were saved after they promised to fast for a certain number of days. These tropes of snakes, of people being lifted up to the top of

14 As others in Aceh told me, it is common that people sense their death forty days in advance. They sense it without being fully aware of it, so they may give signs or say goodbye without being aware that they are doing this. 
the mosque and of survival after a promise or prayer, came up in the stories of various people I spoke with and appeared in different magazines and books about the tsunami. ${ }^{15}$

The stories of pre-tsunami signs that predicted the disaster build on the notion of predestination. Some people sensed that their own death was coming and although people with ilmu (special knowledge) warned for the disaster, most ordinary people only recognized the signs afterwards, when they became objects of interpretation and commentary or when they realized that a personal dream had actually announced the disaster. As some people explained to me, God does give signs and warnings, but they are implicit; in dreams, in children's behaviour. Apart from confirming that the disaster and death were fated, these signs and the miracles that happened during the tsunami emphasized that the tsunami as well as the fate of individuals were part of a divine plan. In many respects, they connect to a broader repertoire of tsunami explanations and their consequences for present and future behaviour.

It is important to note that many people in Aceh discuss dealing with fate or destiny in terms of qadha and qadhar (Smith 2012, 202-206). As Catherine Smith shows in her excellent ethnography of the concept of trauma in Aceh, qadha is the fixed destiny of each individual, determined by God (op. cit. 202). The individual has the obligation to accept qadha. Death is always qadha and thus needs to be accepted. Qadhar, however, is "a form of potential destiny that an individual ought to strive toward." (ibid.). As Smith points out, individuals have to recognize what is qadha and what is qadhar, then accept qadha and strive toward achieving qadhar (ibid.). This distinction is important to keep in mind in the discussion of the tsunami explanations below. While many people in Aceh see the tsunami itself as predetermined fate that has to be accepted, the various explanations they give for the occurrence of the disaster inform their narratives on improvement in the present and the future.

\section{Tsunami Explanations}

Most people told me that the heavy earthquake in the Indian Ocean had caused the tsunami, but the deeper explanation of why this had happened to Aceh (or

15 See, for example, "Tabib Diselamatkan Ular" (Tabib saved by a snake), Aceh Magazine (April 2006, 40-42) and various stories in Tsunami dan Kisah Mereka (The tsunami and their stories) (Damanhuri bin Abbas et al. 2006, Banda Aceh: Badan Arsip Provinsi NAD), such as "Dua Kali Menyelam" (Two times gone under) (70-71) and "Ular Kiri Kanan" (Snakes to the left and to the right) (200-201). 
to a person in particular) was almost always framed in religious terms. ${ }^{16}$ The tsunami was then alternately explained as a test, a warning, a punishment, or a way to stop the conflict. ${ }^{17}$ These explanations often overlapped and many people mentioned several explanations at once. Therefore, rather than describing them as mutually exclusive options, they can be seen as part of a dynamic religious repertoire. In this section, I explore some of the explanations within this repertoire that have important consequences for ideas about the present and the future. As we will see, these different explanations come up in different contexts. For example, while the tsunami was often explained as a test or a warning when people talked about the individual lessons they learned from the disaster, interpretations of the tsunami as a way to stop the conflict or as a punishment for sins that had been committed were often invoked when reflecting on (hoped for) societal changes. To clarify this, in the rest of this section I will discuss some of these explanations in detail.

People often explained the occurrence of the tsunami as a test or trial (cobaan). God had given the people of Aceh (as a group or as individuals) a difficult trial through which they could show the strength of their faith (iman). In addition, by overcoming the disaster, they would strengthen their faith even more. Some people emphasized that the tsunami was thus given to the Acehnese people because God loved them and therefore had given them the opportunity to pass this test. For Ibu Wira, a woman in her late thirties, this was the most important explanation in her process of coming to terms with the disaster. In a long conversation in December 2007, exactly three years after the disaster, she told me how she lost her only daughter in the tsunami and how this still made her extremely sad. However, after the tsunami she had started to increase her religious understanding through reading and praying and because of that she felt a little better every day. She referred to this process as one of individual introspeksi, saying that the tsunami had been a test that offered her the opportunity to move up a grade (naik kelas). Her learning and praying were

16 This line of reasoning is also used by Islamic scholars and religious teachers. For example, in a book titled Tsunami, Tanda Kekuasaan Allah ("Tsunami, a sign of God's power"), Abdurrahman al Baghdady explains that the statement that earthquakes and tsunamis are just natural phenomena is wrong. He argues that they are indeed natural phenomena, but that God decides when they occur (Abdurrahman al Baghdady 2005, 64-72). For a more elaborate discussion of theological perspectives on the tsunami in books, articles, and online publications, see Idria (2010).

17 For other overviews of different explanations, see Fanany (2010), Idria (2010) and Feener (2013). Wieringa (2011) analyses how religious interpretations of the tsunami are reflected in tsunami poetry. 
therefore not only a crucial way to deal with her grief, but also a conscious effort of personal ethical improvement (Kloos, this volume), resulting from the interpretation of the tsunami as a test. While for Ibu Wira this was an individual process, others perceived of the tsunami as an opportunity for the Acehnese to become more pious collectively.

Frequently, people explained the tsunami as a direct consequence of the conflict in Aceh. They would say, for example, that the disaster was God's way to 'wipe Aceh clean' (sometimes the English word cleaning was used), because of the chaos (kekacauan). Chaos in this context referred to the conflict that had troubled the province for decades and that had heavily impacted daily life in Banda Aceh in the last years before the tsunami. ${ }^{18}$ More than eight months after the disaster (in August 2005), the conflicting parties signed a peace agreement. Although other factors were arguably much more fundamental for this agreement to come about (Aspinall 2009), many of Banda Aceh's residents saw peace as a direct consequence of the disaster-and the tsunami thus as God's way to enforce peace. ${ }^{19}$ Such was the view of Pak Ilham, a man in his early thirties, who lived in a village that was hit hard by the tsunami. On an afternoon in 2008, I spoke with Pak Ilham and his wife about the tsunami and the reconstruction process. We were sitting in a tsunami aid house that they temporarily rented from a family member, while waiting for their own house to be finished. After they both told me about what happened to them during the tsunami, Pak Ilham explained why, according to him, the tsunami had happened. His words reveal not only the perceived relation between the conflict and the tsunami, but also the sense of the tsunami as a radical break with the past providing a new beginning:

According to us [the tsunami] is a warning. Perhaps here everything had gone too far already. First, if we look at it from this perspective, there was the conflict. There were murders; houses were burned down, that kind of things. Chaos (kekacauan); let it be over at once. Like that. God gave [it]: everything was over. Cleaning. Clear [English], clean, cleaned up. To begin a new life. That is it, according to my personal opinion.

One explanation is then that God was angry because of the violence in Aceh. However, according to many, God was also angry because of the profusion of

18 For a long time the conflict was heavily felt only in rural Aceh. It was only after the end of Suharto's rule in 1998 that the conflict started to encompass also the urban areas of the province, including Banda Aceh (Miller and Bunnell 2010).

19 See Waizenegger and Hyndman (2010) for a discussion of the relation between the tsunami and the peace process. 
sinful behaviour and moral degradation. 'Sin' in this context was sometimes referred to as dosa, the general Indonesian term for sin, but more often as maksiat, which is generally used in the meaning of sexual immorality. As women are often bestowed with the burden of guarding sexual morality, maksiat is a gendered concept. ${ }^{20}$ This attention to moral degradation and sexual immorality can be seen as part of a broader trend of growing moral vigilantism and public attention to women's dress and moral behaviour. ${ }^{21}$ Michelle Miller (2010) points out how some religious leaders argued that the tsunami was caused by women's immoral conduct. However, though often referring to maksiat as a plausible cause, the Acehnese people I spoke with rarely explicitly blamed women as a group for causing the tsunami. Nevertheless, this narrative of the tsunami as a punishment for sins feeds best into the rhetoric of moral lectures given by religious leaders that focus on the future in order to change the present; and the present in order to change the future (see below). ${ }^{22}$

In this respect, one particular tsunami explanation kept re-appearing. According to this explanation, on the evening before the tsunami (Christmas, 25 December 2004) people were having a party near the grave of Syeikh Abdurrauf Singkil, a famous Islamic scholar from the seventeenth century. He is also widely known as Teungku Syiah Kuala and the grave is usually referred to as the Syiah Kuala grave. According to many, the people partying near the grave that night were Indonesian military, i.e. non-Acehnese. They drank lots of alcohol and 'played with women' (main perempuan), sins according to Islam. The guard of the grave warned them that they should stop the party, but they did not, which aroused the wrath of God. The next day the tsunami struck Aceh as a direct punishment for what happened.

Several things stand out in this story that has a very broad circulation. First of all, even though people often mention that the partygoers were 'playing with women,' the emphasis is clearly on men as the wrongdoers, who would not

$20 \quad$ I thank David Kloos for bringing this to my attention.

21 On the rise of vigilantism with regards to supposed moral transgressions in Aceh, see Kloos (2014) and Newman (2009).

22 Miller's broader argument is that because people saw the disaster as divine punishment for their sins, feelings of guilt made them accept the strict Shari'a rules rather easily. Although divine punishment is one important explanation, I think we should be cautious in depicting guilt as the pervasive feeling. Arguably, while divine punishment is the explanation most often adopted by religious leaders, interpreting the tsunami as a warning or a test given because God loves the Acehnese is of similar importance in society at large. Concomitantly, guilt may have been only one among a range of sentiments of which in the long term, for example, that of acceptance seemed to be much more important. 
listen to the guard and aroused God's anger. Secondly, many people describe the men on the beach as military men. Thus, the story of what happened near Syiah Kuala's grave connects the narratives of immorality and of conflict chaos as explanations for God's decision to send the tsunami.

Finally, in this story, apparently a very small group of wrongdoers caused the deaths of 170,000 people. Interestingly, across the whole repertoire of tsunami explanations, individual and collective responsibilities are alternately invoked. While Ibu Wira saw the tsunami as something she could personally learn from, in other narratives the disaster was a collective test given to the Acehnese, or a sign for the whole Islamic umma that the end of the world was near (see below). Further, individual deaths were explained both on collective and individual levels. One explanation that was often offered, was that for each sinful person ten others had to be taken as well. An explanation for the death of loved ones, especially children, was also that God had chosen those whom he loved most. In this context, one woman emphasized that not the people who survived, but those who were in heaven with God now were saved (selamat). ${ }^{23}$

One recurrent tsunami explanation with profound implications for present behaviour was that the tsunami was a warning (peringatan). God sent the tsunami to remind the Acehnese that the Day of Judgment (kiamat), ${ }^{24}$ on which they will be confronted with their sins, was near. However, the survivors still had some time to change; to improve their conduct and become good Muslims. In informal conversations about the tsunami, the people I have quoted in this chapter as well as many others frequently brought up religious explanations as well as the hope for a better future. These topics were also often discussed in more public settings, such as the neighbourhood women's meeting to which I will turn now.

\section{Religious Improvement}

On a Saturday afternoon in May 2009 I join the monthly neighbourhood arisan (women's gathering rotating savings club). The hostess has invited a religious teacher (ustadz) to give a lecture. After a long prayer ustadz Ibrahim begins to talk about the tsunami, stating that in spite of the tsunami there are still many people who are committing sins. We should

\footnotetext{
23 She deliberately played with the word selamat here, as it can both mean that someone survived (the disaster) and that someone was 'saved' (and in heaven now).

24 Kiamat (Ar. qiyama) in Islam is the Resurrection that follows the annihilation of the world and precedes the Judgment (Gardet 2011).
} 
be aware that our soul (rohani) and our heart are important, not our material possessions (harta). He goes on to explain that the tsunami is already announced in the Qur'an. What is also announced is that there will be signs that the end of the world is drawing near. Nowadays there are more and more disasters, the $u s t a d z$ explains; even today there has been a disaster in Nigeria. The world is old, seven thousand years old, and we only have some centuries left. But actually, we do not know this and the Day of Judgment may even be tomorrow. The tsunami came because of the multiplicity of sins committed in Aceh. It is not because God does not love us. He does love us, but the tsunami was a warning. And actually this warning did not (yet) amount to anything; it lasted only ten minutes.

The ustadz then tells the story of the prophet Musa and the seven plagues in Egypt to explain how God sends tests and warnings and concludes that those trials were much heavier than the ten minutes of the tsunami. He finishes his lecture by saying that people have to pay attention to God's signs. When the world ends, everything you have done will be revealed. And then you will regret that you did not give money to orphans. We should not care about money, because we cannot take money with us to the grave.

Field notes, May 2009

Ustadz Ibrahim was studying abroad during the disaster and lost most of his family members who had stayed behind in Aceh. Drawing on texts from the Quran, he explains the disaster as a warning. The warning is directly related to the future end of the world, since in his religious lesson one's moral behaviour now will influence one's position on the Day of Judgment. His use of the disaster to warn his listeners for committing sins echoes the many lectures and teachings of religious leaders who emphasize that through the tsunami God punished the Acehnese for their sins. As can be understood from ustadz Ibrahim's lecture, this explanation not only installs guilt. It also explicitly leaves room for hope. God gave the tsunami because He loves the Acehnese; He warns them, because He wants to save them. The apocalyptic message of the approach of the Day of Judgment may instil fear, but at the same time it opens up an opportunity. If only people learn from this disaster and become good Muslims, God may have mercy.

It is in this context that survivors like Ibu Wira, who was also present at the meeting, saw the disaster as an opportunity, as something from which they could learn. Another woman from her neighbourhood, who also interpreted the tsunami as an opportunity to become more pious, was Ibu Agustina. She was married, had three school-going children and came from an upper mid- 
dle class family. After the tsunami she had been hesitant about returning to the totally destroyed neighbourhood, but when she saw the house being constructed she slowly started to feel like moving back. While sitting comfortably together in her big, totally reconstructed house, Ibu Agustina told me elaborately about her interpretation of the tsunami as God's will. She emphasized that many of the things she owned now were bigger and more beautiful than the ones she had owned before the tsunami. On the other hand, she argued that after the tsunami she cared less about beautiful things; it was mostly other family members, such as her husband, who chose to have these things. Nevertheless, she was happy to accept this as God's will as well, as fortune (rezeki).

When the tsunami hit, Ibu Agustina was visiting relatives in an inner city neighbourhood. She was hit by the water, but managed to save herself and her daughter who was with her by climbing on a house. Like many others, at that time she thought that the end of the world had come (kiamat):

At the time of the tsunami, Anne, when I was safe from the water, there was only one thing on my mind: according to our religion, if we die we take our sins (dosa) and our merits (pahala) with us. The question is of which there is more, the merits or the sins. So what was on my mind was that I did not bring anything! I have many sins, but no merits. My worshipping was still irregular (bolong bolong, lit. 'with holes in it'), I had made many promises, my clothes were wrong, too tight.

She went on to tell me how she changed this after the tsunami. She changed her dress and prayers, but also her attitude toward other people. Now, she often felt like giving things to others and so she gave money to orphans, saying: "I am afraid that when I die my merits will be too few; that it won't be enough." However, she also said that those who died during the tsunami would be in heaven:

We, as Muslims, think that the people who died during the tsunami will have a place in heaven in the afterlife (akhirat). They died as martyrs ( mati syahid). People cry for them, but actually we should cry for ourselves who are still here. They will be in heaven, but for us it is yet uncertain. We should just surrender (pasrah).

Schielke (2009b) has argued that we should not only pay attention to people's ideals of pious behaviour, but also to the outcomes, the failures and tensions these ideals may cause. Ibu Agustina seemed to feel uneasy about living in a beautiful house with a huge television and a refrigerator that was much bigger 
and more beautiful than the one she had owned before the disaster, as this seemed to contrast with the pious position of not valuing material possessions. Although people do not necessarily have solutions in case of moral dilemmas (ibid.), in this case she did propose a solution by using the notion of rezeki to explain that this luxury was not her own wish. In this way she positioned herself in relation to normative religious ideas about material possessions.

Although many people said that the tsunami was meant to improve moral behaviour, they also complained about the lack of moral improvement in present society. Many Acehnese told me that apparently people were 'still not aware,' referring to shops staying open during the evening prayer (maghrib), young people going out late at night, and the moral danger of the internet. On the other hand, many of the same people complained about the lack of entertainment in Banda Aceh. Pious behaviour is then, as anthropologists of Islam have remarked, not the only moral framework or aim in people's everyday lives (Marsden 2005, 2009; Schielke 2009a, 2009b). Nevertheless, the enormous attention to the relation between the tsunami and personal as well as collective moral change influenced at least some people's actual behaviour, as well as post-tsunami religious institutional reform (see Feener this volume; Feener 2013; Lindsey et al. 2007; Miller 2010).

\section{Forebodings of the Final End}

Returning then to the tsunami explanations in Aceh, the sense of a final end makes both the tsunami (as a warning, punishment, or test) and present actions meaningful. Present social actions are influenced by the expectation of an end, because by their present conduct people can influence their personal end (on the Day of Judgment). This is what Ibu Agustina sought to establish by changing her behaviour. The sense of an ending thus establishes a relation between the individual and his or her position in the end, after death and on the Day of Judgment. If the tsunami is interpreted as an immediate consequence of past sinning, however, present collective conduct can also influence the (near) future of Aceh. This is the immediate conclusion from a warning that was painted in graffiti on some unused roadblocks. It said: 'awas maksiat, stunami [sic] dekat, mari kita berdoa,' which can be translated as 'beware of sin, the tsunami is at hand, let us pray' The assumption is clear: if people sin (again), another tsunami will come soon. Numbers in red on these same roadblocks are counting down: $3^{-2-1}$. It is not sure that the numbers are connected to the message, but if they are, their meaning seems obvious. Thus, present actions influence both the near and the ultimate future. 
Like ustadz Ibrahim, Ibu Agustina told me that the tsunami, together with other disasters in Indonesia, was a sign that the end of the world was near. As noted above, to many people the tsunami itself seemed to be the end of the world and only when it was over they realized it was not. In the apocalypse there can be different 'ends' (Kermode 1967, 89). Next to the ultimate end of the world (that stops time), there are the great crises in human life that do not stop time (ibid.). They seem to be the apocalypse, "but the world goes forward in the hands of the exhausted survivors" (op. cit. 82). In Aceh, the great crisis of the tsunami made the final end (kiamat) immanent and imminent (Kermode 1967). Although the apocalyptic idea is nothing new, it is through the framework of crisis of the tsunami that it becomes imminent and immediately relevant to the present. It means that time is running out for changing one's behaviour. Moreover, frequent crises in Indonesia and abroad are interpreted as a sign that the Day of Judgment is near. While many people only in retrospect recognized that their dreams and other signs had foreshadowed the tsunami, now the tsunami itself was interpreted as a sign of the end that gives meaning to the present. The tsunami therefore made the religious temporality of an end time more present, thereby increasing the need for present and future religious improvement.

Although the end cannot be evaded, there may be hope. As we have seen above, many people interpret the tsunami as a test (tes, cobaan). The tsunami made many victims for whom the disaster was the personal end. But the survivors lived through this 'end' and people like Ibu Wira and Ibu Agustina see this as an explicit personal opportunity to be morally good persons and add up to their religious rewards (pahala). They interpret their survival as a personal second chance. Moreover, living through the tsunami and its aftermath has made them, as many people say, more aware (sadar) of their religious duties. Without denying that these narratives may instil guilt and fear, I would say that for many people they are primarily ways to come to terms with the terrible disaster in accordance with their most profound beliefs. As I emphasized above, different explanations of the tsunami as a test, a warning, or a punishment are not mutually exclusive. Neither are the feelings of guilt, submission, acceptance, devotion, and becoming aware of religious duties. They are all ways of making sense of the past in the present.

\section{Hikmah}

As we have seen above, the interpretation of the tsunami as given by God as part of a divine plan and as foreshadowing the end of the world, urged for 
people's moral improvement in the present. But many Acehnese related the certainty that the tsunami was God's will also to other kinds of post-tsunami improvements, such as the peace agreement and increased social and economic well-being. Rather than something people were urged to work upon, these improvements were seen as almost a direct effect of the tsunami. The way in which these different kinds of improvement became entangled in the interpretation of the tsunami as part of a divine plan is clearly seen in how people used the concept of hikmah (divine wisdom).

The concept of hikmah, often translated as 'wisdom' but also related to 'truth,' 'knowledge,' and 'perfection,' has been mostly elaborated in Sufi philosophy. Throughout Islamic history it has also been identified with intellectual sciences in general (Nasr 2006, 37). Since the early period of Islam, it has had a wide range of connotations and there is no single fixed meaning of the concept throughout the Quran (Yaman 2011, 1-4). Hikmet Yaman shows how according to early Muslim commentators, "there is a causal relationship between sincere piety and being given hikmah $[\ldots]$ " $(2011,3)$, and that according to the Qur'an, "God is the ultimate possessor of hikmah" (ibid.). The concept can be understood very broadly as "all knowledge within the reach of man" (Goichon 2011). For early Muslim mystics, "real knowledge of everything, including hikmah, is not a matter of rational "knowing," but existential "being": hikmah is a process of knowing" (Yaman 2011, 270). Nasr describes how for many early Islamic philosophers, hikmah meant both knowledge and the way it is practiced (Nasr 2006, $36-38$ ).

Although exact lines of entrance of the concept of hikmah into Acehnese Islam have not yet been mapped, it is likely that one line of transmission was through the work of the twelfth-century scholar Al-Ghazali and later through the Sufi work of the nineteenth-century Sumatran scholar Abd al-Samad alPalimbani. ${ }^{25}$ Interestingly, the Acehnese descriptions of hikmah in the tsunami as both God's wisdom and the positive effects of this divine intervention in the world echo the close relation between hikmah as both knowledge and practice that is found with the early Islamic philosophers described by Nasr.

The idea that there was divine wisdom in the tsunami (tsunami ada hikmah) usually came up in conversations about material and social improvement; when discussing things that got better after the tsunami. By evoking the concept of hikmah, people suggested that the tsunami was part of God's plan to

25 R. Michael Feener, personal communication. On the work of Abd al-Samad al-Palimbani, see Kaptein (2013). 
do something good for them, to bring about improvement-ranging from a religious lesson or warning to improvement of the political and economic situation.

When Pak Nazaruddin, the shop owner, and I talked in his shop about the meaning of the tsunami, he formulated two forms of tsunami hikmah:

If God gives us a test, in the end there will be hikmah in it. [...] After what happened here, with people losing their parents and others, the Acehnese could have had stres now. But because they have a strong religion, a strong faith, they would think 'this test will have hikmah.' What that hikmah is? Well, for example. That young man, Tarmizi, did not have a house before the tsunami. Now he owns a house. That is hikmah. And then there is the second hikmah. Before the tsunami, there was an ongoing conflict in Aceh. That ended because of the tsunami. ${ }^{26}$

While the idea of the tsunami as a test through which the Acehnese should strengthen their faith was pervasive in what Pak Nazaruddin told me, his idea of hikmah was rather related to livelihood improvement. Significantly, this use of the concept of hikmah calls attention to a broader development of increasing entanglement between Islamic religious ideals and modern technologies of development (see Feener 2013). It is important to note that both Pak Nazaruddin and I knew that the young man, Tarmizi (see below), had lost many family members during the tsunami and had great difficulties in making ends meet financially. By explaining the concept of hikmah, then, Pak Nazaruddin obviously did not mean that the tsunami had been only good for them. Rather, it meant that the disaster was part of a divine plan and that in the long term it was meant to improve certain things. According to Pak Nazaruddin, it was this realization that kept people from going mad.

In Pak Nazaruddin's explanation, hikmah is both per definition part of the test that God gave to the people and can be seen in the effects of this test (such as better houses and the peace agreement). Others also spoke of hikmah as something people received (dapat) through the tsunami. As indicated above,

26 A discussion on Islam and grieving in post-tsunami Aceh is beyond the scope of this chapter. However, this remark of Pak Nazaruddin represents a more general idea that people did not go mad because of their faith. Stres, as he uses it and different from Western psychology, refers to serious mental disorder and is in this context often interchangeably used with gila, mad. Interestingly, this speaks not only to the pious self-identification of many people in Aceh, but also to the magnitude of the grief - without faith, going mad would be a real possibility. 
this could mean material improvement in the form of houses and objects, the peace agreement, or for example the post-tsunami international attention. However, in other contexts hikmah could also refer to the religious lesson that people learned from the tsunami, often in relation to its interpretation of being a test or a warning as discussed above. This latter meaning of hikmah ties in to Sufi traditions of 'wisdom' that are imparted by religious teachers and spiritual guides.

Different imaginaries of present and future improvement are entangled in these uses of the concept of hikmah as divine wisdom and its practice or effects in the world. The narrative of improvement through development (including amelioration of living conditions), however, also ties in to a broad, more secular, development discourse that became very influential in the post-tsunami years.

\section{Building Back Better}

As captured in the different uses of the notion of hikmah, aspirations for change included a variety of ideas about personal and social improvement. Schielke (2009b, 172) argues that:

[...] the development of global capitalism, corresponding practices of production and consumption and the aspirations of progress and a better life have become a fundamental constituent of people's expectations and experiences even in the most remote places [...]

He notices that "consumption and moral practice have become intertwined in a complex way as key modalities of aspiring to and realizing happiness [...]" (ibid.). Aspirations for both moral improvement and material development were very influential in post-tsunami and post-conflict Aceh. Both of these aspirations were created and expressed by many institutions (such as the national government, international organizations, religious institutions, and NG Os), as well as by ordinary Acehnese. Concerning the improvement narrative of socio-economic development, it was especially the younger generation that voiced their aspirations to earning a lot of money and living a middle class lifestyle.

However, both younger and older people often spoke of their hopes for Aceh as a province to become more prosperous. In this often sketched image of the future, economic prosperity went together with a strong Islamic identity. It was often in this context of a future imaginary, including Islam and prosperity, that 
people evoked the idea of Aceh's glorious past, in which the region was at once Islamic, prosperous, and cosmopolitan. As with the concept of hikmah discussed above, this is another example of how the narratives of moral improvement and socio-economic development come together. In the remainder of this section, I will discuss the latter narrative; the influential improvement narrative of socio-economic development. Before taking a look at the ideas about development and the future of Aceh in the narrative of a young man, Tarmizi, I will briefly discuss the influential institutional promotion of the development discourse and ask how and where the state's discourse on the future meets with ordinary people's expectations.

From 2005 onwards, the BRR (Badan Rehabilitasi dan Rekonstruksi, Rehabilitation and Reconstruction Agency) and many of its reconstruction partners (NGOs and other international aid agencies) started to use the slogan "Building Back Better" to argue that Aceh would not only be reconstructed, but even made much better than it ever was. The joint report of the BRR and a number of its partners that came out one year after the disaster is titled: "Aceh and Nias one year after the tsunami: the recovery effort and way forward." The one year report of the BRR (April 2006) is called "Building a land of hope." Finally, the title of the first of a series of books published at the end of BRR's term is "Tsunami: from disaster to the emergence of light" (BRR 2009). The first two reports featured pictures of children playing and smiling, and the Acehnese working hard to rebuild their houses. The latter book indeed ends with a picture of the sun shining on an Acehnese mountain. In the public statements of many humanitarian agencies and the BRR, the focus has been squarely on reconstruction and the bright future that lies ahead. Few references were made to the death and grief of the tsunami or the conflict. Often, the tsunami is even described as an opportunity and a starting point for this better future.

The optimistic message that was so often voiced by the reconstruction agency and its partners was related, of course, to their own task of rebuilding. It was a political message of a government that was unpopular during the years of conflict (and still much criticized during the reconstruction process). It was the message of a government that therefore had everything to win by focusing on the future; a bright future that in fact seemed to be beyond the official term of the BRR (which ended in April 2009) and the reconstruction projects of most international agencies. Moreover, as Anderson (1998) shows, the image of going from darkness to light as a message of social and political transition has a long history in Indonesia. ${ }^{27}$ In Banda Aceh, this image has been given a particularly

27 See Siegel (2000 [1969], 122) on the idea of modernist Islam as 'light' after darkness in Aceh. 
concrete form through the experiential architecture of the Tsunami Museum (see Samuels 2012, 171-174).

The 'building back better' narrative leaves little room for discussing failures of the past, remembering the conflict and mourning the tsunami dead. The progressive focus on rebuilding toward the future and 'the way forward' also leaves little room for discussing stumbling blocks on that 'way' and other pressing issues (such as rebuilding the local government, politics, and corruption). The continuous use of phrases such as 'building back better,' 'the way forward' and Aceh being in 'transition' evoked the idea of a 'better future' (see also Feener 2013). However, the agencies that took responsibility for the reconstruction process only stayed for a short while and would certainly be gone once that future would arrive. The narrative is thus one of continuous progress without an end point in the future-although projects through which progress should materialize had clear end points.

Importantly, different voices with different visions of improvement come with different interests. These voices are not equal in terms of power relations. Yet while Indonesian government officials may have endorsed certain improvement ideas due to particular political interests, these ideas could also gain in power because the expectation of improvement was widespread in society at large. Rather than being a one-way process of powerful institutions developing and disseminating improvement narratives that are in their own interest to an ignorant population, these narratives develop and intersect in a complex field of social relations that have evolved in Aceh over time. While state actors develop and spread their ideas about the future, they cannot prescribe how people imagine their future and interpret the present. It is precisely by looking at the ways in which ordinary people appropriate and adapt official discourses and create ideas about the present and the future in their everyday lives, that we can grasp the limits of the state.

In April 2009, the BRR's term officially ended and the assets as well as the leftover problems were handed over to a short-term transitional agency (BKRA) and the provincial government. ${ }^{28}$ Many international humanitarian agencies and donors had left already and others were busy finishing and evaluating their projects. Only a few of them pledged to stay after 2009. In the same month legislative elections were held and for the first time local political parties were allowed to participate. ${ }^{29}$ The province had entered another period of 'transition' facing substantial political and administrative changes.

28 See "Post-reconstruction Aceh: Leftover problems." Jakarta Post, 26 December 2009.

29 See Barter (2011) for an analysis of the 2009 elections. 
It was at this time that I met Tarmizi. He, like so many others, was worried about the economic situation. Also, many people were concerned about the peace process; not only in light of the upcoming elections, but also because many international organizations were leaving. According to many Acehnese, their presence, even if it was for tsunami reconstruction projects, had contributed to political stability. Now that the attention of 'the world' moved to other regions and countries, uncertainty increased. Concerning the future, many people said that they hoped it would be 'better' (lebih baik), for Aceh and for themselves. Tarmizi's ideas resonate with many imaginaries of the future I came across in Banda Aceh's neighbourhoods. They give us an idea of what this 'better' could mean.

Tarmizi was in his early thirties and had lost his parents and many of his extended family members in the tsunami. He married less than a year after the disaster, and in 2009 he lived with his wife and his three-year-old son in a newly built tsunami-house in his old neighbourhood. Their living conditions were poor, in part because Tarmizi did not have a steady job. Despite his difficult situation, he often told me how he kept the spirits up (tetap semangat). He frequently connected his ideas for the future of Aceh to his hopes for the future of his son, whom he wanted to give a good education:

Aceh has changed because of the new buildings and infrastructure, but also for example in the area of education. We have better technologies now. Schools teach more languages. Before, we used to learn English. Now they also offer Japanese, Dutch, French, and Arabic. After the tsunami, education has much improved. Every school now has a lab (laboratory) with computers. Before, I did not know how to handle a computer. Now primary school children know how to do it. There is the internet; it is a time of major change. [...] I really hope that Aceh will be more developed (maju) in the future. That is, in the sense of technological development and of education. We should improve Aceh in the sense of education. It is important that [our students] go to the Netherlands, to America, and to Germany to learn. Then they can bring pride to Aceh, because of their knowledge (ilmu tinggi). Aceh does not want to lose, does not want to retreat; it wants to go forward/develop (maju). Today, we see how extraordinary the world outside (dunia luar) is; the food and electronic products that they [people outside Aceh] can make. Aceh will also be like them.

Later, Tarmizi also sketched the relations between these 'modern' developments and 'traditional' community values: 
Together we rebuilt our neighbourhood. It is something we did together; we never lost hope, we went on struggling. [...] [I value] both the ordinary people and the modern people (masyarakat awam dan masyarakat moderen). In this neighbourhood we use a certain system, it is like a symbol. It means that we do not use modern languages, languages that people may not know, modern languages that they perhaps do not understand. So, because of the everyday mingling with the people, I use Acehnese, even though I do speak Indonesian and English. By using the right language in the right place, people won't feel jealous. If they do not speak Indonesian, they do not feel side-lined.

All the people I met in his neighbourhood spoke Indonesian well (like almost everyone in Banda Aceh). One could say that Tarmizi here adopts a paternalistic attitude of knowing better than his neighbours. Although that may be so, I would also argue that it points to a specific aspect of what he sees as 'modernity' and what he sees as a better future for Aceh. Modernity in this perception is associated with 'the world outside,' with things people can adopt from this world outside - predominantly knowledge and technologyand the tools to do this-predominantly language and education. 'Ordinary' language, in Tarmizi's account, is needed to keep cohesion, while 'modern' language is needed to advance, to develop. Improvement, for Tarmizi, has everything to do with Aceh's place-in-the-world (Ferguson 2006), with the 'outside world' recognizing Aceh as a 'modern' player, so that "Aceh will also be like them."

While Tarmizi's account resonates with the state's development discourse, pointing to a change toward modernity in education and language, it also reformulates this discourse in a much more globalized way, by defining modernity in terms of international relations and skills. His idea of the future of Aceh reflects his subjectivity and positioning with his background of a community broker with NGO contacts as well as his plans for his son. At the same time, it reflects an image of Aceh's past and future that was widespread among ordinary people in Aceh during the post-tsunami years. Tarmizi's reflections therefore give us a sense of how imaginaries of Acehnese futures are produced and reproduced; influenced but never totally determined by the state.

As I have argued throughout this chapter, in post-tsunami Aceh these future imaginaries were often framed in relation to the notion of the tsunami as an opportunity to improve oneself and society both morally and socio-economically. In this regard, BRR has called the tsunami a 'blessing in disguise' (BRR 2009, 95, cited in Feener 2013). Many people in Aceh would rather think of it as hikmah. 


\section{Conclusion}

People in Aceh saw the tsunami as a starting point for improvement in different ways. As a destined event predetermined by divine wisdom, many people thought of the disaster as revealing a divine message as well as showing that they were part of God's plan. Many Muslims in Aceh understood the tsunami in an Islamic temporality, in which one's own death and the end of the world are predetermined. In this perspective, during their time in the world, people can improve themselves and society. For many, the tsunami was a God-given warning, punishment, or test that revealed the need for such improvements. The idea of the tsunami as an opportunity for moral change was for many people entangled with the idea that the disaster was a starting point for the amelioration of everyday living conditions or 'development.'

This narrative of improvement as development came to expression in a context of (inter)national attention for 'building back better' and concurrent 'expectations of modernity, building on a development discourse framed in a temporality of linear progress. However, in everyday Aceh, it also built on an idea of Aceh and Aceh's place-in-the-world that has developed over the last century. This idea of Aceh's place-in-the-world is constituted by a temporality of nostalgia that underlies the aspiration for Aceh's 'return' to its glorious past of Islamic rule and economic prosperity. This future imaginary strongly connects improvement narratives of Islam and socio-economic development, a relation that more broadly inspires attempts of social engineering that have developed in Aceh since the second half of the twentieth century (Feener 2013).

In this chapter, I have identified another important way in which the improvement narratives of Islam and socio-economic development were brought together by my Acehnese interlocutors, namely through the Islamic concept of hikmah (divine wisdom). Discussing the tsunami in terms of hikmah, they connected the idea of the disaster as a God-given opportunity for change with expectations of and aspirations for moral and socio-economic improvement.

Institutional discourses are very influential in creating future imaginaries, yet they do not totally determine the dynamics of these and other imaginaries in everyday life. Throughout this chapter, I have focused on the imaginaries of the future of ordinary Acehnese and suggested that temporalities of Islam and development intersect in Acehnese understandings of the tsunami and the future in the process of the post-disaster remaking of society. They do so through narratives of improvement that are part of official policies, but also acquire their fluid forms in the fine-grained dynamics of the everyday. It is 
exactly in their everyday expectations and aspirations that people creatively appropriate and adapt state discourses, while imagining and shaping their own futures and the future of Aceh.

\section{References}

Abdurrahman al Baghdady. 2005. Tsunami, Tanda Kekuasaan Allah. Jakarta: Cakrawala Publishing.

Agamben, Giorgio. 2001. “Das Unheilige Leben.” Interview by Hanna Leitgeb and Cornelia Vismann. Literaturen 2(1):16-22.

Anderson, Benedict. 1983. "Old State, New Society: Indonesia's New Order in Comparative Historical Perspective." Journal of Asian Studies 42(3):477-496.

1998. The Spectre of Comparisons: Nationalism, Southeast Asia, and the World. London: Verso.

Appadurai, Arjun. 2004. "The Capacity to Aspire: Culture and the Terms of Recognition." In Culture and Public Action, edited by Vijayendra Rao and Michael Walton, 59-84. Stanford: Stanford Social Sciences.

Aspinall, Edward. 2009. Islam and Nation: Separatist Rebellion in Aceh, Indonesia. Stanford: Stanford University Press.

Barter, Shane Joshua. 2011. "The Free Aceh Elections? The 2009 Legislative Contests in Aceh." Indonesia 91:113-130.

Birchok, Daniel Andrew. 2013. "Sojourning on Mecca's Verandah: Place, Temporality and Islam in an Indonesian Province." PhD diss., University of Michigan.

Böwering, Gerhard. 1997. "The Concept of Time in Islam." Proceedings of the American Philosophical Society 141(1):55-66.

BRR. 2006. Building a Land of Hope: One Year Report Executing Agency of the Rehabilitation and Reconstruction Agency for Aceh and Nias. B RR report.

BRR. 2009. Tsunami: From Disaster to the Emergence of Light. Jakarta: Multi Donor Fund/UNDP.

BRR and partners. 2005. Aceh and Nias One Year After the Tsunami: The Recovery Effort and Way Forward. BR report.

Buchanan-Smith, Margaret and Simon Maxwell. 1994. "Linking Relief and Development: An Introduction and Overview." Institute of Development Studies Bulletin 25(4):2-16.

Christoplos, Ian and Treena Wu. 2012. "Linking Relief, Rehabilitation and Development (LRRD) to Social Protection: Lessons from the Early Tsunami Response in Aceh." In From the Ground Up: Perspectives on Post-Tsunami and Post-Conflict Aceh, edited by Patrick Daly, R. Michael Feener and Anthony Reid, 40-56. Singapore: ISEAS. 
Fanany, Ismet. 2010. “Afterword: Reconstructing the Invisible Landscape.” In Post-Disaster Reconstruction: Lessons from Aceh, edited by Matthew Clarke, Ismet Fanany and Sue Kenny, 235-249. London: Earthscan.

Fealy, Greg and Sally White, eds. 2008. Expressing Islam: Religious Life and Politics in Indonesia. Singapore: ISEAS.

Feener, R. Michael. 2013. Sharía and Social Engineering: The Implementation of Islamic law in Contemporary Aceh. Oxford: Oxford University Press.

2011. "The Acehnese Past and its Present State of Study." In Mapping the Acehnese Past, edited by R. Michael Feener, Patrick Daly and Anthony Reid, 1-24. Leiden: KITLV press.

Feener, R. Michael and Patrick Daly. Forthcoming. "Religion and Reconstruction in the Wake of Disaster." Asian Ethnology.

Ferguson, James. 1999. Expectations of Modernity. Berkeley: University of California Press.

2006. Global Shadows: Africa in the Neoliberal World Order. Durham: Duke University Press.

. 2008. "Global Disconnect: Abjection and the Aftermath of Modernism." In Readings in Modernity in Africa, edited by Peter Geschiere, Birgit Meyer and Peter Pels, 8-16. Bloomington: Indiana University Press.

Gardet, L. 2011. "Kiyāma." In Encyclopaedia of Islam, Second Edition, edited by P. Bearman, Th. Bianquis, C.E. Bosworth, E. van Donzel, and W.P. Heinrichs. Leiden: Brill. [online access]

Goichon, A.M. 2011. "Hikma." In: Encyclopaedia of Islam, Second Edition, edited by P. Bearman, Th. Bianquis, C.E. Bosworth, E. van Donzel, and W.P. Heinrichs. Leiden. Brill. [online access].

Grayman, Jesse H., Mary-Jo Delvecchio Good, and Byron J. Good. 2009. “Conflict Nightmares and Trauma in Aceh." Culture, Medicine, and Psychiatry 33:290-312.

Green, Nile. 2003. "The Religious and Cultural Roles of Dreams and Visions in Islam." Journal of the Royal Asiatic Society 13(3):287-313.

Heryanto, Ariel. 1988. “The Development of 'Development'.” Indonesia 46:1-24.

Idria, Reza. 2010. "Muslim Theological Perspectives on Natural Disasters: the Case of Indonesian Earthquakes and Tsunami of 2004." MA Thesis, Leiden University.

Ihsan, Sehat. 2010. "Kenduri Kematian di Kluet Aceh Selatan: Pemaknaan yang Beraneka Ragam.” In Serambi Mekkah yang Berubah: Views from Within, edited by Arskal Salim and Adlin Sila, 253-284. Jakarta: Pustaka Alvabet and Aceh Research Training Institute.

Kaptein, Nico J.G. 2013. “Abd al-Ṣamad al-Palimbānī.” In Encyclopaedia of Islam, Three, edited by Gudrun Krämer, Denis Matringe, John Nawas and Everett Rowson. Leiden: Brill. [online access].

Kennedy, James, Joseph Ashmore, Elizabeth Babister and Ian Kelman. 2008. "The 
Meaning of 'Building Back Better': Evidence from Post-Tsunami Aceh and Sri-Lanka." Journal of Contingencies and Crisis Management 16(1):24-36.

Kermode, Frank. 1967. The Sense of an Ending: Studies in the Theory of Fiction. New York: Oxford University Press.

Kloos, David. 2013. "Becoming Better Muslims: Religious Authority and Ethical Improvement in Aceh, Indonesia." PhD diss., vU University Amsterdam.

. 2014. "In the Name of Syariah? Vigilante Violence, Territoriality, and Moral Authority in Aceh, Indonesia." Indonesia 98:59-90.

- Forthcoming. "Images of Violence and Piety in Aceh." In Islam, Politics and Change: the Indonesian Experience, edited by Kees van Dijk and Nico Kaptein. Leiden: Leiden University Press.

Leland de la Durantaye. 2009. Giorgio Agamben: A Critical Introduction. Stanford: Stanford University Press.

Li, Tania Murray. 1999. "Compromising Power: Development, Culture, and Rule in Indonesia." Cultural Anthropology 14(3):295-322. 2007. The Will to Improve: Governmentality, Development, and the Practice of Politics. Durham and London: Duke University Press.

Lindsey, Tim, and M.B. Hooker, with Ross Clarke and Jeremy Kingsley. 2007. "Shari'a Revival in Aceh." In Islamic Law in Contemporary Indonesia, Ideas and Institutions, edited by R. Michael Feener, and Mark E. Cammack, 216-254. Cambridge: Harvard University Press.

Marsden, Magnus. 2005. Living Islam: Muslim Religious Experience in Pakistan's NorthWest Frontier. Cambridge: Cambridge University Press.

. 2009. "A Tour not so Grand: Mobile Muslims in Northern Pakistan." Journal of the Royal Anthropological Institute (N.s.):S57-S75.

Miller, Michelle A. 2010. "The Role of Islamic Law (Sharia) in Post-Tsunami Reconstruction." In Post-Disaster Reconstruction: Lessons from Aceh, edited by Matthew Clarke, Ismet Fanany and Sue Kenny, 29-6o. London: Earthscan.

Miller, Michelle A. and Tim Bunnell. 2010. "Urban-Rural Connections: Banda Aceh through Conflict, Tsunami and Decentralization.” Working paper, Asia Research Institute, National University of Singapore.

Nasr, Seyyed Hossein. 2006. Islamic Philosophy from its Origin to the Present: Philosophy in the Land of Prophecy. New York: State University of New York Press.

Newman, Sarah J. 2009. "Patrolling Sexuality." Inside Indonesia 96.

Njoto-Feillard, Gwenaël. 2012. L'Islam et la Réinvention du Capitalisme en Indonésie. Paris: Karthala, IISMM.

Otayek, Renee and Benjamin Soares. 2007. "Introduction: Islam and Muslim Politics in Africa." In Islam and Muslim Politics in Africa, edited by Benjamin Soares and Renee Otayek, 1-24. Basingstoke: Palgrave Macmillan.

Overbeck, Hans. 1929. "Shaer Ta'bir Mimpi." Journal of the Malayan Branch of the Royal Asiatic Society 3:338-375. 
Phelps, Nicholas A., Tim Bunnell and Michelle Ann Miller. 2011. "Post-Disaster Economic Development in Aceh: Neoliberalization and Other Economic-Geographical Imaginaries." Geoforum 42:418-426.

Rudnyckyj, Daromir. 2010. Spiritual Economies: Islam, Globalization and the Afterlife of Development. Ithaca: Cornell University Press.

Samuels, Annemarie. 2012. "After the Tsunami: The Remaking of Everyday Life in Banda Aceh, Indonesia." PhD diss., Leiden University.

Schielke, Samuli. 2009a. "Being Good in Ramadan: Ambivalence, Fragmentation, and the Moral Self in the Lives of Young Egyptians." Journal of the Royal Anthropological Institute (N.s.):S24-S40.

20ogb. "Ambivalent Commitments: Troubles of Morality, Religiosity and Aspiration among Young Egyptians." Journal of Religion in Africa 39:158-185.

Siapno, Jaqueline Aquino. 2002. Gender, Islam, Nationalism and the State in Aceh: The Paradox of Power, Co-optation, and Resistance. London: RoutledgeCurzon.

Siegel, James. 1979. Shadow and Sound: The Historical Thought of a Sumatran People. Chicago: University of Chicago Press.

- 2000 [1969]. The Rope of God. Ann Arbor: The University of Michigan Press.

Smith, Catherine. 2012. "War, Medicine, and Morality in Aceh: An Ethnography of Trauma as an Idiom of Distress." PhD diss., Australian National University.

Snouck Hurgronje, Christiaan. 1894. De Atjehers, Volume 2. Leiden: Brill.

Soares, Benjamin. 2006. "Islam in Mali in the Neo-Liberal Era." African Affairs 105:77-95.

Soares, Benjamin and Filippo Osella. 20og. "Islam, Politics, Anthropology." Journal of the Royal Anthropological Institute (N.s.):S1-S23.

Spyer, Patricia. 200o. The Memory of Trade: Modernity's Entanglements on an Eastern Indonesian Island. Durham and London: Duke University Press.

Waizenegger, Arno and Jennifer Hyndman. 2010. "Two Solitudes: Post-Tsunami and Post-Conflict Aceh." Disasters 34(3):787-808.

Wieringa, Edwin. 1998. "The Dream of the King and the Holy War against the Dutch: The 'Kôteubah' of the Acehnese Epic 'Hikayat Prang Gômpeuni'." Bulletin of the School of Oriental and African Studies 61(2):298-308.

2011. "God Speaks through Natural Disasters, but What Does He Say? Islamic Interpretations in Indonesian Tsunami Poetry." In Aceh: History, Politics and Culture, edited by Arndt Graf, Susanne Schröter and Edwin Wieringa, 316-333. Singapore: ISEAS.

Yaman, Hikmet. 2011. Prophetic Niche in the Virtuous City: The Concept of Hikmah in Early Islamic Thought. Leiden: Brill. 